\title{
EFIKASI Beauveria bassiana TERHADAP HAMA KUTU DAUN (Aphis glycines Matsumura) DAN PENGARUHNYA TERHADAP ORGANISME NONTARGET DAN PERTUMBUHAN TANAMAN KEDELAI
}

\author{
Rosma Hasibuan, Catur Yuniarsih, Indriyati \& Purnomo \\ Jurusan Agroteknologi, Fakultas Pertanian Universitas Lampung \\ Jl. Prof. Soemantri Brodjonegoro, No. 1, Bandar Lampung 35145 \\ E-mail: yunii_11@yahoo.co.id
}

\begin{abstract}
Salah satu faktor yang menyebabkan menurunnya produksi kedelai di Indonesia adalah serangan hama mulai dari awal pertumbuhan hingga panen. Aphis glycines (Homoptera: Aphididae) merupakan salah satu hama penting tanaman kedelai. Salah satu jamur entomopatogen yang potensial sebagai agen pengendali hama adalah Beauveria bassiana. Penelitian ini bertujuan untuk mengetahui pengaruh jamur B. bassiana dalam menurunkan populasi hama A. glycines dan pengaruhnya terhadap organisme nontarget dan pertumbuhan tanaman kedelai. Pengujian dilakukan di Laboratorium Hama Tumbuhan, Jurusan Agroteknologi, Fakultas Pertanian Universitas Lampung dan Kebun Percobaan Lapangan Terpadu, Fakultas Pertanian Universitas Lampung, menggunakan empat perlakuan yaitu kontrol, aplikasi B. bassiana asal isolat Tegineneng, aplikasi $B$. bassiana asal isolat Sumberjaya, dan aplikasi B. bassiana komersial. Percobaan ini disusun menggunakan Rancangan Acak Kelompok (RAK) dan masing-masing perlakuan diulang sebanyak tiga kali. Data yang didapatkan dianalisis ragam dan dilanjutkan dengan uji BNT dengan taraf nyata 5\%. Hasil penelitian menunjukkan bahwa semua isolat yang diuji mampu menginfeksi dan menyebabkan kematian pada A. glycines. Mortalitas A. glycines tertinggi terdapat pada perlakuan B. bassiana komersial yang mencapai 78,33 ekor/4 rumpun tanaman.Hasil penelitian tentang organisme nontarget menunjukkan bahwa aplikasi $B$. bassiana tidak mempengaruhi jumlah famili dan total organisme nontarget. Selain itu hasil penelitian juga menunjukkan bahwa aplikasi $B$. bassiana tidak berpengaruh terhadap tinggi tanaman, jumlah daun, jumlah bunga, dan jumlah polong tanaman kedelai.
\end{abstract}

Kata kunci : Aphis glycines, Beauveria bassiana, efikasi, mortalitas, organisme nontarget.

\section{PENDAHULUAN}

Di Indonesia, kedelai telah menjadi sumber gizi protein nabati utama. Namun saat ini pemenuhan kebutuhan kedelai di Indonesia masih mengandalkan impor akibat rendahnya produksi kedelai lokal. Badan Pusat Statistik (2012) melaporkan bahwa produksi kedelai tahun 2011 turun sebesar 55,74 ribu ton $(6,15 \%)$ dibandingkan tahun 2010. Salah satu faktor yang menyebabkan menurunnya produksi kedelai di Indonesia adalah serangan hama mulai dari awal pertumbuhan hingga panen.

Salah satu hama penting tanaman kedelai adalah kutu Aphisglycines.Kutu ini menyerang pertanaman kedelai sejak awal pertumbuhan hingga panen (Arifinet al., 1997). Hama ini mengisap daun dan batang sehingga kedelai yang terserang hama ini menjadi layu dan terhambat pertumbuhannya karena cairan tanaman habis terisap (AAK, 2007).
Sampai saat ini usaha pengendalian hama pada tanaman kedelai di tingkat petani masih mengandalkan insektisida. Penggunaan insektisida tersebut selain mahal, juga menimbulkan munculnya hama-hama sekunder, pencemaran lingkungan, dan menimbulkan residu insektisida pada komoditi yang dapat membahayakan bagi konsumen. Untuk menghindari kelemahan penggunaan insektisida perlu dikembangkan konsep pengendalian hama terpadu (Rusli, 1999).

Salah satu komponen penting dalam pengendalian hama terpadu adalah pengendalian secara biologis atau hayati dengan memanfaatkan entomopatogen. Salah satu jamur entomopatogen yang potensial sebagai agen pengendali hama adalah B. bassiana (Indriyati, 2009).

Penelitian ini bertujuan untuk mengetahui pengaruh jamur $B$. bassiana dalam menurunkan populasi hama $A$. glycinesdan megetahui pengaruh jamur $B$. bassiana terhadap organisme nontarget dan pertumbuhan tanaman kedelai. 


\section{BAHAN DAN METODE}

Penelitian ini dilaksanakan pada bulan Maret September 2013 di Laboratorium Hama Tumbuhan, Jurusan Agroteknologi, Fakultas Pertanian Universitas Lampung dan Kebun Percobaan Lapangan Terpadu, Fakultas Pertanian Universitas Lampung. Penelitian ini disusun berdasarkan Rancangan Acak Kelompok (RAK) yang dilakukan pada plot-plot percobaan yang masing-masing berukuran $1 \mathrm{~m}$ x $2 \mathrm{~m}$.Terdapat empat (4) perlakuan yang digunakan dalam penelitian ini, adalah: $\mathrm{p}_{0}$ : tanpa penyemprotan $B$. bassiana, $\mathrm{P} 1=$ dengan penyemprotan isolat $B$. bassiana asal Tegineneng, $\mathrm{p}_{2}$ : dengan penyemprotan isolat $B$. bassiana asal Sumberjaya, dan $\mathrm{p}_{3}$ : dengan penyemprotan $B$. Bassiana komersial. Masing- masing perlakuan diulang sebanyak tiga (3) kali. Data yang didapat diuji dengan sidik ragam (ANOVA) yang dilanjutkan dengan uji Beda Nyata Terkecil (BNT) dengan taraf nyata $5 \%$.

Untuk membuat media sabouroud dextrose agar (SDA) dan penyiapan isolat $B$. Bassiana, bahan yang diperlukan yaitu $40 \mathrm{~g}$ dextrose, $15 \mathrm{~g}$ agar, $5 \mathrm{~g}$ kasein, 10 g pepton, dan 11 air destilata. Bahan-bahan tersebut dimasukkan ke dalam tabung Erlenmeyer kemudian diautoklaf selama 2 jam. Media yang telah siap pakai dituangkan ke masing-masing cawan petri dalam ruangan steril (Laminar Air Flow) yang selanjutnya digunakan untuk mengisolasi isolat $B$. bassiana. Isolat B.bassiana yang diuji dalam penelitian ini berasal dari Tegineneng dan Sumberjaya. Sedangkan inokulum B. bassiana komersial yang digunakan yaitu insektisida berbahan aktif konidia $B$. bassiana yang diproduksi oleh BPTP Tegineneng.

Perbanyakan B. bassiana Menggunakan Media Beras. Beras dikukus hingga setengah matang (15 menit), kemudian dikeringanginkan. Setelah beras dingin, sebanyak $100 \mathrm{~g}$ dimasukkan ke dalam plastik tahan panas dan disterilkan dengan autoklaf. Setelah diautoklaf, beras tersebut diangkat dan dikeringanginkan. Kemudian $B$. bassiana diinokulasi dan diinkubasi selama 2-3 minggu.

Pembuatan Formulasi Kering B. Bassiana dilakukan dengan mengeringkan $B$. bassiana yang tumbuh pada media beras di dalam lemari pendingin selama 12 hari. Kemudian beras diblender dan diayak sehingga menjadi tepung biomassa spora. Setelah itu 40 $\mathrm{g}$ tepung biomassa spora dicampur dengan bahan pembawa, yaitu kaolin ( $20 \mathrm{~g}$ ), zeolit (20 g), dan tepung jagung(20 g) untuk menghasilkan formulasi kering sebanyak $100 \mathrm{~g}$. Pembuatan formulasi kering ini mengacu pada Punomo et al. (2012). Penanaman benih kedelai dilakukan dengan caratugalan, yaitu dengan membuat lubang tugal sedalam 3- $4 \mathrm{~cm}$ lalu dimasukkan sebanyak 2 benih kedelai ke dalam tiap lubang tanaman, kemudian ditutup dengan tanah halus dan tipis. Jarak tanam yang digunakan yaitu $30 \mathrm{~cm}$ x $30 \mathrm{~cm}$. Aplikasi $B$. bassiana dilakukan sore hari saat tanaman berumur 3 MST. Penyemprotan dilakukan dengan konsentrasi 25 gram formulasi kering $B$. bassiana untuk satu liter air dengan volume semprot $70 \mathrm{ml}$ per rumpun tanaman.

Pengamatan mortalitas kutu Aphis glycines dilakukan dengan dua metode, yaitu pengamatan secara langsung dan dengan teknik kain hampar. Kain hampar (ground cloth) yang digunakan berukuran $30 \mathrm{~cm}$ x 30 $\mathrm{cm}$. Pengamatan dilakukan setiap hari hingga 7 hari setelah aplikasi. Pengamatan populasi kutu secara langsung dilakukan setelah aplikasi $B$. bassiana. Pengamatan dilakukan setiap hari hingga 7 hari setelah aplikasi.

Pada pengamatan organisme nontarget dengan teknik pitfall trap, Pitfalltrap diisi dengan air sabun kemudian dipasang dengan cara memasukkannya ke dalam tanah. Bagian atas pitfalltrap dinaungi oleh plastic mika. Pitfalltrap yang digunakan sebanyak 3 (tiga) buah pada masing-masing plot percobaan dan dipasang selama 24 jam dan dilakukan hingga 7 hari setelah aplikasi.

Pengamatan dilakukan mulai 1 (satu) minggu setelah tanam. Variabel yang diamati adalah tinggi tanaman dan jumlah daun. Selain itu diamati juga jumlah bunga, jumlah polong, dan berat polong.

\section{HASIL DAN PEMBAHASAN}

Hasil pengamatan mortalitas kutu Aphis glycines dengan teknik pengamatan secara langsung menunjukkan bahwa semua isolat yang diuji mampu menginfeksi A. glycines. Kutu yang terinfeksi ditandai dengan tumbuhnya miselium berwarna putih pada permukaan tubuh A. glycines. Miselium akan terlihat jelas apabila diamati di bawah mikroskop (Gambar 1). Mortalitas tertinggi terdapat pada perlakuan $B$. bassianakomersial dan tidak berbeda nyata dengan kedua isolat lainnya (Tegineneng dan Sumberjaya), namun berbeda nyata dengan perlakuan kontrol.

Pada pengamatan mortalitas kutu Aphis glycines dengan teknik pengamatan menggunakan ground cloth, kutu A. glycines yang terjatuh pada ground cloth tidak terinfeksi $B$. bassiana. Hal tersebut dapat diketahui dari tidak tumbuhnya miselium jamur pada tubuh $A$. glycines. Kematian A. glycines ini diduga karena faktor umur. Selain itu, faktor lingkungan juga dapat menjadi penyebab kematian A. glycines. Hasil pengamatan menunjukkan bahwa mortalitas tidak berbeda nyata antarperlakuan hingga hari ketujuh setelah aplikasi. Hasil 
pengamatan menunjukkan bahwa populasi A. glycines mengalami penurunan setiap harinya. Suryawan dan Oka (1992) mengungkapkan bahwa keberadaan $A$. glycines di lapangan di pengaruhi oleh beberapa faktor lingkungan, seperti curah hujan, keadaan pertanaman, dan musuh alami.

Terdapat 13 famili artropoda tanah (populasi organisme nontarget) yang terjebak dalam pitfall trap, antara lain Formicidae, Carabidae, Gryllidae, Lycosidae, Apidae, Tettigoniidae, Chrysomelidae, Pentatomidae, Carcinophoridae, Acrididae, Blatidae, Silphidae, dan Braconidae.Selain 13 famili tersebut, pada petak percobaan diluar tanaman sampel, ditemukan juga golongan musuh alami A. glycines, yaitu famili Coccinellidae dan famili Syrphidae. Namun data kepadatan populasi dari kedua famili ini tidak didapatkan karena sifat dari kedua famili yang aktif bergerak. Berdasarkan pengamatan yang telah dilakukan selama
6 minggu menunjukkan bahwa tanaman kedelai mengalami pertambahan tinggi setiap minggunya, namun tidak ada perbedaan yang signifikan antarperlakuan (Gambar 2). Sama seperti tinggi tanaman, hasil pengamatan juga menunjukkan bahwa jumlah daun tidak mengalami perbedaan yang signifikan antarperlakuan (Gambar 3).

Berdasarkan pengamatan diketahui bahwa tidak ada perbedaan jumlah bunga dan polong polong pada setiap perlakuannya. Jumlah bunga dan polong tidak berbeda nyata antarperlakuan (Gambar 4 dan Gambar 5). Secara umum, hasil pengamatan menunjukkan bahwa berat brangkasan maupun jumlah polong tidak berbeda nyata pada setiap perlakuannya. Pada brangkasan basah, berat brangkasan tertinggi terdapat pada perlakuan $B$. bassiana komersial, sedangkan pada brangkasan kering, berat brangkasan tertinggi terdapat pada isolat $B$. bassiana Tegineneng.
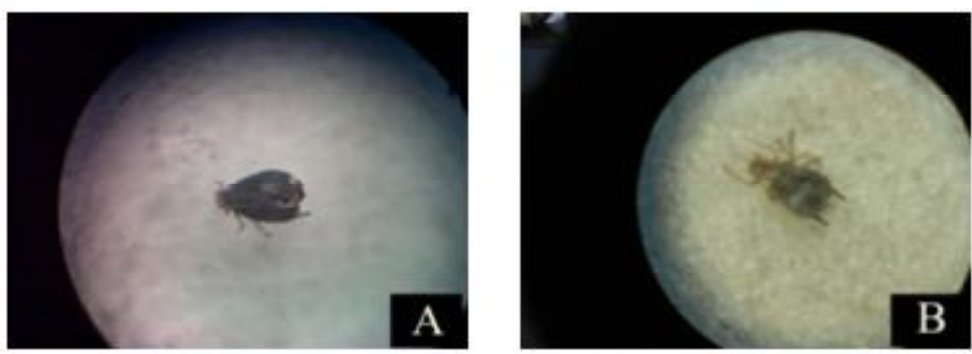

Gambar 1. Kutudaun Aphis glycines yang dilihat di bawah mikroskop: A) Aphis glycines sehat; B) Aphis glycines yang terinfeksi Beauveria bassiana.

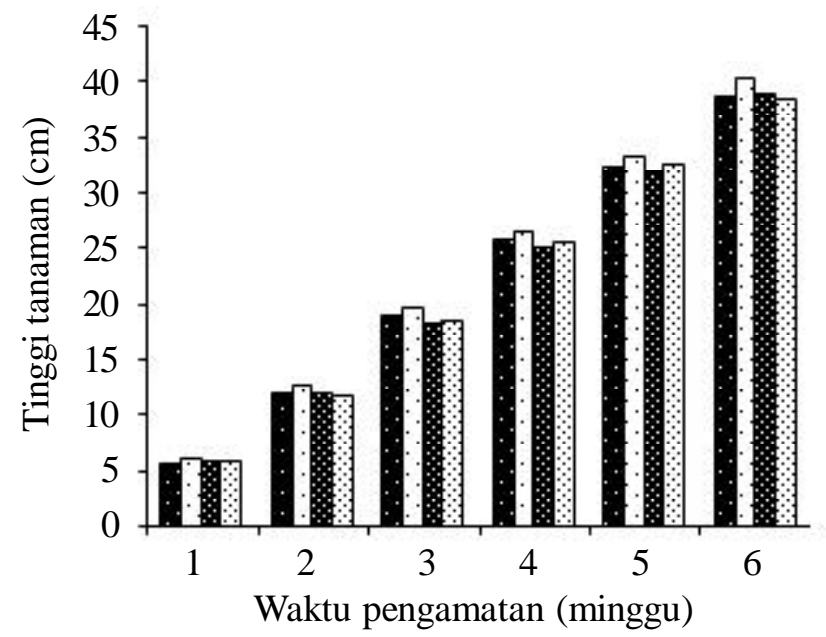

Gambar 2. Grafik rata-rata tinggi tanaman kedelai selama 6 minggu pengamatan; $\mathrm{P} 0(\mathrm{C})=$ Kontrol; $\mathrm{P} 1(\square)=B$. bassiana Tegineneng; $\mathrm{P} 2$ (网) = B. bassiana Sumberjaya; P3 (圈) = B. bassiana komersial.

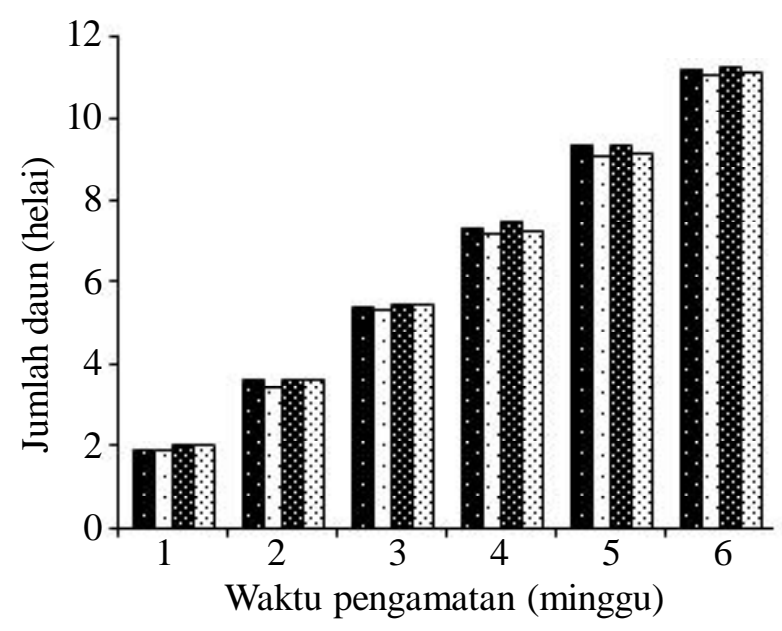

Gambar 3. Grafik rata-rata jumlah daun tanaman kedelai selama 6 minggu pengamatan; $\mathrm{P} 0$ ( $=$ Kontrol; P1 $\square=$ B. bassiana Tegineneng; P2 (絪) $=B$. bassiana Sumberjaya; P3 (圈) = B. bassiana komersial. 


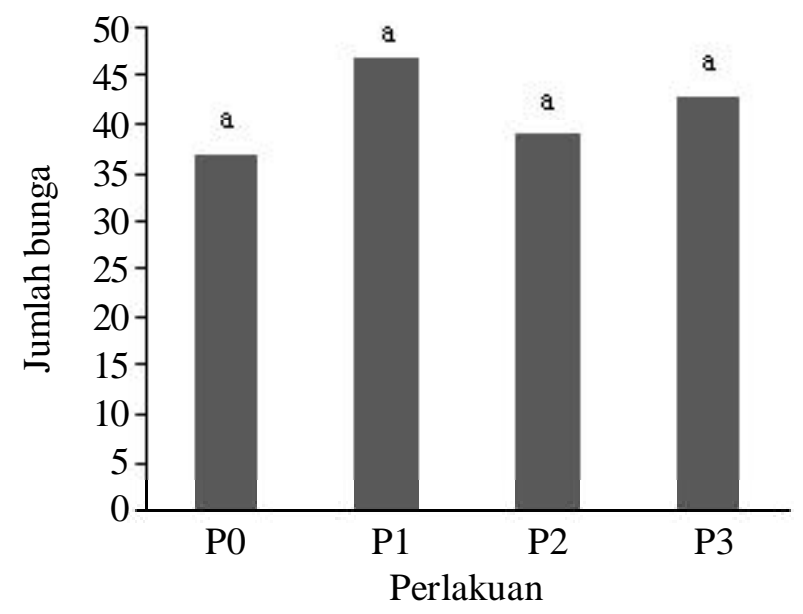

Gambar 4. Grafik rata-rata jumlah bunga tanaman kedelai pada $5 \mathrm{mst} ; \mathrm{P} 0=$ Kontrol; $\mathrm{P} 1=$ $B$. bassiana Tegineneng; $\mathrm{P} 2=B$. bassiana Sumberjaya; P3 = B. bassiana komersial.

\section{KESIMPULAN}

Jamur $B$. bassiana mampu menginfeksi dan menyebabkan kematian terhadap hama A.glycines, serta berpengaruh terhadap populasi A. glycines. Aplikasi B. bassiana tidak berpengaruh terhadap jumlah famili dan total organisme nontarget. Aplikasi $B$. Bassiana juga tidak berpengaruh terhadap pertumbuhan tanaman kedelai.

\section{DAFTAR PUSTAKA}

AAK. 2007. Kedelai. Kanisius. Yogyakarta.

Arifin, M., Iqbal A., Suryawan, I. B. G., Djuwarso T., dan Tengkono, W. 1997. Potensi dan Pemanfaatan Musuh Alami dalam Pengendalian Hama Kedelai. Prosiding Simposium Penelitian Tanaman Pangan. Jakarta/Bogor, 23-25 Agustus 1993.

Badan Pusat Statistik. 2012. Produksi Padi, Jagung, dan Kedelai (Angka Tetap 2011 dan Angka Ramalan I 2012). Berita Resmi Statistik No. 43/07/Th. XV, 2 Juli 2012.

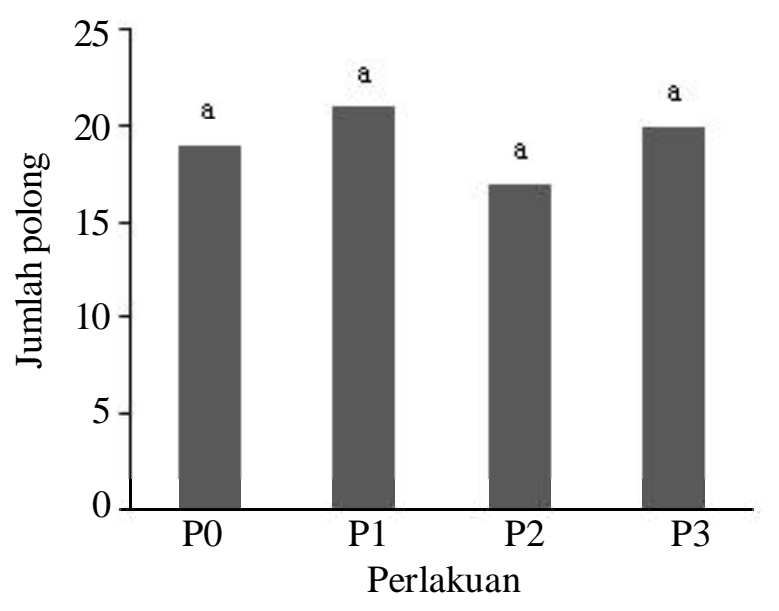

Gambar 5. Grafik rata-rata jumlah polong tanaman kedelai pada 6 mst; $\mathrm{P} 0=$ Kontrol; $\mathrm{P} 1=$ $B$. bassiana Tegineneng; $\mathrm{P} 2=B$. bassiana Sumberjaya; $\mathrm{P} 3=$ B. bassiana komersial.

Indriyati. 2009. Virulensi Jamur Entomopatogen Beauveria bassiana (Balsamo) Vuillemin terhadap Kutudaun (Aphis spp.) dan Kepik Hijau (Nezara Viridula). J. HPT Tropika 9(2):92-98.

Purnomo., Aeny, T. N., dan Fitriana, Y. 2012. Pembuatan dan Aplikasi Formulasi Kering Tiga Jenis Agensia Hayati untuk Mengendalikan Hama Pencucuk Buah dan Penyakit Busuk Buah Kakao. Laporan Penelitian Hibah Bersaing. Bandar Lampung.

Rusli, R. 1999. Biologi Aphis glycines Matsumura (Homoptera: Aphididae) pada Beberapa Tingkat Umur Kedelai (Glycine max (L.) Merrill). $J$. Natur Indonesia II (1):80-84.

Suryawan, I.B.G. dan Oka, I.N. 1992. Bioekologi Serangan Dan Pengendalian Hama-Hama Pengisap Daun Kedelai. Risalah Lokakarya Pengendalian Hama Terpadu Tanaman Kedelai Balittan Malang, Malang. $116 \mathrm{hlm}$. 